\title{
Surgical treatment of postinfarction left ventricular aneurysm in 32 patients
}

\author{
R. M. Donaldson, M. Honey, R. Balcon, S. O. Banim, M. F. Sturridge, and J. E. C. Wright \\ From the London Chest Hospital, London
}

Thirty-two patients with large postinfarction left ventricular aneurysms shown at operation to consist of fibrous tissue are reported. All had angina and/or breathlessness, and none had a history of embolism. Thirty were correctly diagnosed by left ventricular cineangiography. Two of the 3 patients with inferior and 1 with an anterior aneurysm had associated ventricular septal defects, and 3 patients with an anterior aneurysm had mitral regurgitation. All had major coronary arterial lesions and 68 per cent had double or triple vessel disease. The aneurysm was excised in all patients; in 15 this was combined with saphenous vein bypass grafting of coronary arteries supplying surviving myocardium, in 3 with closure of a ventricular septal defect, and in 3 with mitral annuloplasty or replacement. Operative mortality was 6.2 per cent, and 79 per cent of the survivors are asymptomatic with average follow-up period of 18 months after operation.

Postinfarction ventricular aneurysm has been shown to have a poor prognosis (Schlichter, Hellerstein, and Katz, 1954). In addition patients often suffer from exertional dyspnoea associated with a high left ventricular end-diastolic pressure, and from angina due both to increased wall tension in the surviving myocardium (Austen et al., 1962) and to disease of coronary arteries supplying it. For these two reasons, it is appropriate to consider patients for surgical management.

We are reporting here our experience with 32 patients in whom a ventricular aneurysm was excised. In comparing reported series of patients, a major problem is one of definition. Our series includes only those patients who at operation were found to have transmural fibrous scars, clearly delineated from the surrounding muscle, and collapsing when suction was applied to the ventricular vent; the fibrotic nature of the wall of the aneurysm was confirmed by pathological examination of the excised specimen. In many but not all, aneurysm was suspected from the left ventricular angiogram. We have, however, found, like others (Gorlin, Klein, and Sullivan, 1967; Yacoub et al., 1973), that paradoxical outward bulging in systole (dyskinesis) of scarred or poorly perfused but viable myocardium may simulate aneurysm, and that some aneurysms may show akinetic segments but no

Received 10 June 1976. dyskinesis on the left ventricular angiogram. Some (e.g. Dubnow, Burchell, and Titus, 1965) only classify as aneurysm those scars that are associated with localized protrusion of the external wall of the ventricle as well as of the ventricular cavity. On the other hand, Schlichter, et al. (1954) and Mourdjinis et al. (1968) include those cases in which there is no external bulge, described by the latter authors as 'minor aneurysms'; our definition which is based on surgical pathological criteria includes such cases.

\section{Patients}

The 32 patients fulfilling these criteria were seen between April 1971 and April 1975. In many of these, ventricular aneurysm was suspected from the clinical features. In most of the others, all of whom were being investigated for coronary heart disease because of symptoms, aneurysm was recognized on the left ventricular angiogram. In 2 the presence of aneurysm was substantiated only at operation.

\section{Clinical data (Table 1)}

There were 27 men and 5 women ranging in age between 27 and 71 years (average 54). Twenty-nine of the patients complained of dyspnoea ${ }^{1}$ (average grade 3 ) and in 25 this was a dominant symptom;

${ }^{1}$ Angina and dyspnoea were graded 1 to 4 according to $\mathrm{New}$ York Heart Association criteria. 
TABLE 1 Clinical details

\begin{tabular}{|c|c|c|c|c|c|c|c|c|c|}
\hline Case & Age & Sex & Dyspnoea & Angina & & Limiting & Electrocardiogram & Chest radiograph & Therapy \\
\hline No. & $(y)$ & & $\begin{array}{l}\text { Grade Duration } \\
\text { (mth) }\end{array}$ & Grade & $\begin{array}{l}\text { Duration } \\
\text { (mth) }\end{array}$ & symptom & & & $\begin{array}{l}\text { Beta- Digoxin/ } \\
\text { adrenergic diuretic } \\
\text { blocking } \\
\text { agent }\end{array}$ \\
\hline
\end{tabular}

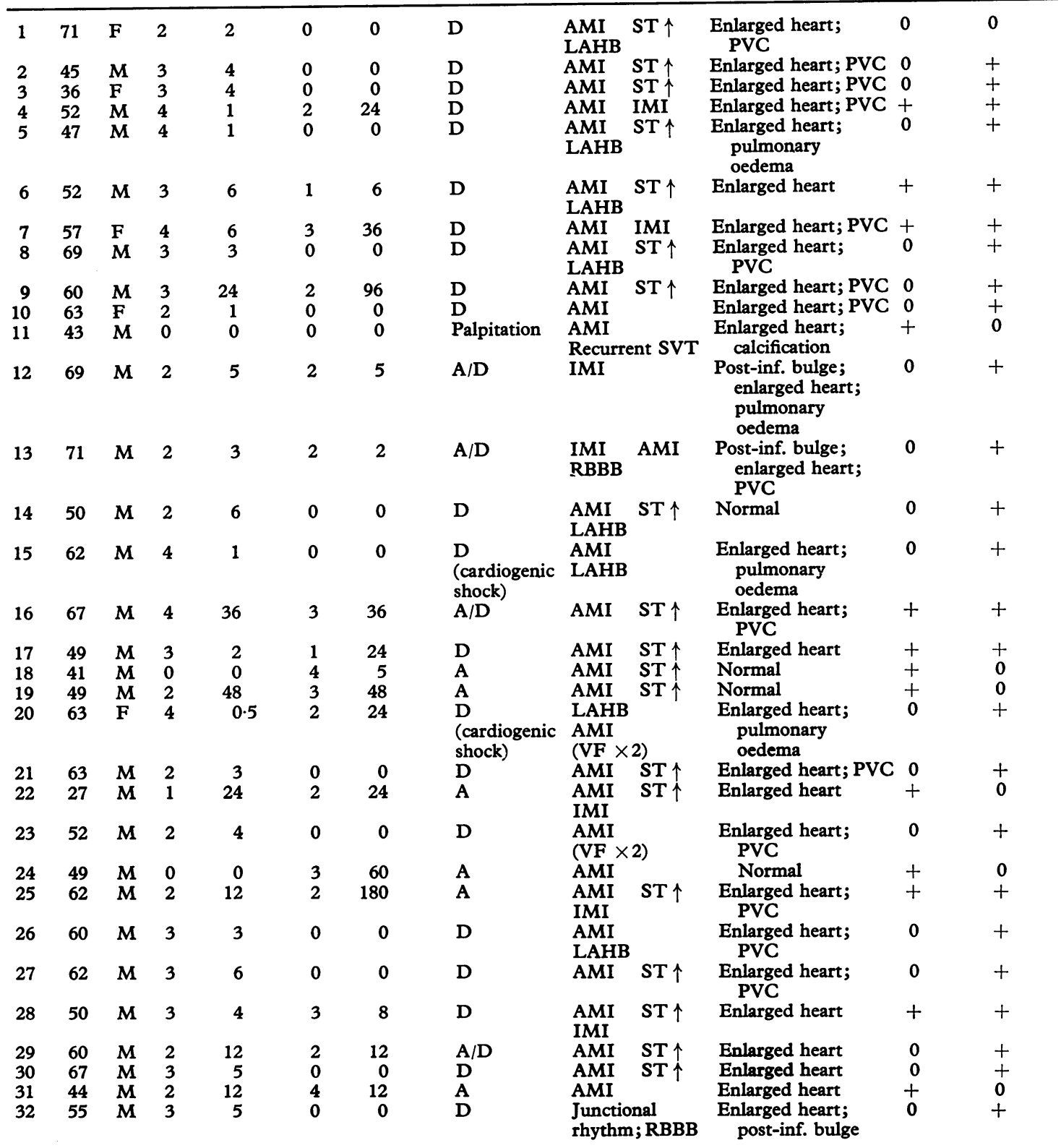

A, angina; D, dyspnoea; AMI, anterior myocardial infarction; IMI, inferior myocardial infarction; ST $\uparrow$, persistent ST segment elevation; LAHB, left anterior hemiblock; SVT, supraventricular tachycardia; VF, ventricular fibrillation; PVC, pulmonary venous congestion. 
6 patients had dyspnoea at rest, including 2 who were in cardiogenic shock after recent myocardial infarction. Seventeen patients had angina but this was a dominant symptom in only 6 . One patient was investigated because of recurrent tachyarrhythmias. All patients had had a previous myocardial infarct between 1 and 16 months before admission, with a typical history and electrocardiogram, and usually enzyme changes; 8 patients had had two such episodes. Two patients had a history of hypertension, one was diabetic, and 19 were smokers. No patient had a history suggestive of arterial embolism. Twenty-five patients were on treatment with digitalis and diuretics for congestive heart failure and 13 with beta-adrenergic blocking agents.

\section{Investigations}

The resting electrocardiogram was abnormal in all, showing evidence of transmural ( $Q$ wave) anterior infarction in 24, inferior in 1 , and anterior and inferior in a further $6 .^{1}$ In 19 patients there was persistent ST segment elevation present for at least 6 months or since infarction if the history was shorter. Left anterior hemiblock (Rosenbaum, Elizari, and Lazzari, 1970) was present in 8. One patient had right bundle-branch block, but no pathological $Q$ waves.

Recurrent supraventricular tachyarrhythmia was recorded in 1 patient, and another had an atrioventricular junctional rhythm. The chest radiograph showed cardiomegaly and/or pulmonary venous congestion in 28 patients, in 4 of whom there was pulmonary oedema. Calcification in the wall of the aneurysm was seen in 1 patient, an abnormality of the left heart border was observed in 22 patients, and a posteroinferior bulge was seen in the lateral radiograph in 3. In 4 patients the cardiac contour was normal. The left ventricular enddiastolic pressure ranged from 6 to $40 \mathrm{mmHg}$ with a mean of $22.3 \mathrm{mmHg}$ (Table 2 ).

The left ventriculogram showed paradoxical movement in systole in 30 patients, of the anterior wall in 27, and of the inferoposterior wall in 3 . In the other 2 cases akinetic segments were seen. Three of the patients with an anterior aneurysm had moderate to severe mitral regurgitation. Ventricular septal defects were present in 2 patients with posteroinferior aneurysms and in 1 patient with an anterior aneurysm. A filling defect compatible with a large thrombus was seen in 10 patients.

Selective coronary angiography was performed in 30 patients, using the Sones technique in all except 1 ; each major coronary vessel was graded from 0 to 4

${ }^{1}$ Electrocardiographic criteria for infarction were those of McConahay et al. (1970). on the coronary arteriogram: 0 - normal, 4 - complete occlusion, and 1 to 3 - stenosis of increasing severity. Eight patients had major lesions (grade 3 or 4) of a single vessel, 12 of two vessels, and 10 of three. Two of those with triple vessel disease had additional left main coronary artery stenosis.

\section{Operation}

Three patients had an emergency operation. One of these was admitted in cardiogenic shock 4 weeks after a myocardial infarction; the second deteriorated abruptly after catheterization, and the third was investigated because of a persistent low output state following two episodes of ventricular fibrillation which had been rapidly terminated by cardioversion. The remaining 29 patients had elective procedures.

Operation was carried out using standard normothermic cardiopulmonary bypass. The heart was electrically fibrillated, to prevent embolization which might be caused when handling the heart.

The aneurysms as defined were easily identified thin-walled bulges of the left ventricle. Suction on the left ventricular vent produced collapse of the thin-walled area in all cases. This manoeuvre was useful in delineating the area to be resected. On incising this area the line of demarcation between the viable myocardium and the fibrous aneurysm was easily identified. There were pericardial adhesions overlying the aneurysm in 25 patients. Organized mural thrombus was found in 19 patients. The aneurysm was excised and the left ventricular wound repaired using polypropylene sutures without buttressing with prosthetic material. The major vessel supplying the aneurysmal area was found to have a total or subtotal block in all cases and was not grafted.

Additional operative procedures were undertaken in 18 patients. Fifteen underwent concomitant saphenous vein bypass grafting of vessels not involved in the aneurysm: 7 patients had a single graft, 7 had two grafts, and 1 had three grafts. Aortocoronary bypass was performed by interposition of autologous saphenous vein between the aorta and distal coronary artery, using a single continuous suture for the anastomosis. Two patients with mitral regurgitation, resulting from chordal rupture in 1 and partial papillary muscle rupture in the other, had mitral valve replacement, and a third required annuloplasty. The septum was scarred in most cases, and in 3 patients there were postinfarction ventricular septal defects which were repaired through the open aneurysm. There were 2 surgical deaths (operative mortality $6 \cdot 2 \%$ ) resulting from myocardial failure. One of these patients was 
TABLE 2 Results of investigation and operation

\begin{tabular}{|c|c|c|c|c|c|c|c|c|c|c|c|}
\hline \multicolumn{5}{|c|}{$\begin{array}{l}\text { Results of investigation } \\
\text { Case Left } \quad \text { Grading of coronary } \\
\text { No. ventricular artery lesion }\end{array}$} & \multirow[t]{2}{*}{ Other } & \multicolumn{2}{|c|}{$\begin{array}{l}\text { Operation } \\
\text { Left } \\
\text { ventricular } \\
\text { aneurysm } \\
\end{array}$} & \multirow[t]{2}{*}{$\begin{array}{l}\text { Additional } \\
\text { procedure }\end{array}$} & \multirow[t]{2}{*}{$\begin{array}{l}\text { Follow-up } \\
\text { Duration } \\
\text { (mth) }\end{array}$} & \multirow[t]{2}{*}{ Symptoms } & \multirow[t]{2}{*}{ Treatment } \\
\hline & $\begin{array}{l}\text { end-diastolic } \\
\text { pressure } \\
\text { (mmHg) }\end{array}$ & $\begin{array}{l}\text { Left } \\
\text { anterior } \\
\text { descend- } \\
\text { ing }\end{array}$ & $\begin{array}{l}\text { Left } \\
\text { circum- } \\
\text { flex }\end{array}$ & Right & & Site & $\begin{array}{l}\text { Approx. } \\
\text { excised } \\
\text { area }\left(\mathrm{cm}^{2}\right)\end{array}$ & & & & \\
\hline 1 & 37 & 4 & 0 & 0 & & Ant. & 56 & & 56 & $\begin{array}{r}\text { Dyspnoea } \\
\text { grade } 2\end{array}$ & $\begin{array}{l}\text { Digoxin, } \\
\text { diuretic }\end{array}$ \\
\hline 2 & 25 & 4 & 2 & 1 & & Ant. & 56 & & 46 & None & None \\
\hline 3 & 15 & 4 & 0 & 0 & MR 3/4 & Ant. & 70 & $\begin{array}{l}\text { Mitral valve } \\
\text { replacement }\end{array}$ & 42 & None & None \\
\hline 4 & 33 & 3 & 4 & 3 & & Ant. & 40 & & Died $16 \mathrm{~m}$ & nth after operati & tion \\
\hline 5 & 40 & 4 & 2 & 3 & & Ant. & 150 & & 30 & None & None \\
\hline 6 & 28 & 4 & 3 & 1 & & Ant. & 120 & & 30 & $\begin{array}{l}\text { Angina } \\
\text { grade } 2\end{array}$ & $\begin{array}{l}\text { Beta- } \\
\text { blocker, } \\
\text { digoxin, } \\
\text { diuretic }\end{array}$ \\
\hline 7 & 28 & 4 & 3 & 4 & & Ant.-apical & 45 & VG to RCA & 26 & None & None \\
\hline 8 & 15 & $\star$ & $\star$ & * & $M R 3 / 4$ & Ant. & 40 & $\begin{array}{l}\text { Mitral valve } \\
\text { replacement }\end{array}$ & 26 & None & $\begin{array}{l}\text { Digoxin, } \\
\text { diuretic }\end{array}$ \\
\hline 9 & 11 & 4 & 3 & 3 & & Ant. & 50 & $\begin{array}{l}\text { VG to RCA } \\
\text { and } C F X \text {; } \\
\text { E to RCA }\end{array}$ & 26 & $\begin{array}{l}\text { Angina } \\
\text { grade } 2\end{array}$ & $\begin{array}{l}\text { Beta- } \\
\text { blocker }\end{array}$ \\
\hline 10 & 35 & 4 & 3 & 3 & & Ant. & 150 & & 21 & None & None \\
\hline 11 & 12 & 3 & 2 & 3 & & Ant. & 60 & & 20 & None & None \\
\hline 12 & 20 & 3 & 3 & 4 & VSD & $\begin{array}{l}\text { Post- } \\
\text { inf. }\end{array}$ & 15 & $\begin{array}{l}\text { Closure VSD; } \\
\text { VG to RCA } \\
\text { and CFX }\end{array}$ & 17 & $\begin{array}{r}\text { Dyspnoea } \\
\text { grade } 2\end{array}$ & Diuretic \\
\hline 13 & 35 & 3 & 3 & 4 & VSD & $\begin{array}{l}\text { Post- } \\
\text { inf. }\end{array}$ & 6 & $\begin{array}{l}\text { Closure VSD; } \\
\text { VG to LAD } \\
\text { and CFX }\end{array}$ & 17 & None & Diuretic \\
\hline 14 & 10 & 4 & 0 & 0 & & Ant. & 40 & & 15 & $\begin{array}{l}\text { Postoperative } \\
\text { arrhythmias }\end{array}$ & $\begin{array}{l}\text { Beta- } \\
\text { blocker }\end{array}$ \\
\hline 15 & 40 & 4 & 4 & 3 & & Ant. & 120 & & Died at of & peration & \\
\hline 16 & 20 & 4 & 2 & 3 & & Ant.-apical & 180 & & Died at of & peration & \\
\hline 17 & 15 & 4 & 2 & 0 & & Ant.-apical & 60 & & 14 & None & None \\
\hline 18 & 20 & 4 & 3 & 3 & & Ant. & 15 & $\begin{array}{l}\text { VG to LAD } \\
\text { and RCA }\end{array}$ & 14 & None & None \\
\hline 19 & 10 & 3 & 2 & 3 & & Ant. & 28 & VG to LAD & 14 & None & None \\
\hline 20 & 20 & 4 & 2 & 0 & VSD & Ant. & 49 & $\begin{array}{l}\text { Closure of } \\
\text { VSD }\end{array}$ & 13 & None & $\begin{array}{l}\text { Beta- } \\
\text { blocker, } \\
\text { diuretic }\end{array}$ \\
\hline 21 & 6 & * & * & * & & Ant. & 70 & & 10 & None & None \\
\hline 22 & 15 & 4 & 2 & 3 & & Ant. & 32 & $\begin{array}{l}\text { VG to RCA } \\
\text { and CFX; } \\
\text { E to RCA }\end{array}$ & 10 & None & None \\
\hline 23 & 15 & 4 & 0 & 0 & & Ant.-apical & 45 & & 10 & None & Diuretic \\
\hline 24 & 10 & 4 & 2 & 4 & & Apical & 21 & $\begin{array}{l}\text { VG to LAD } \\
\text { and RCA; } \\
\text { E to RCA }\end{array}$ & 7 & None & None \\
\hline 25 & 12 & 4 & 3 & 4 & & Apical & 54 & $\begin{array}{l}\text { VG to RCA; } \\
\text { CFX, and } \\
\text { LAD }\end{array}$ & 7 & None & $\begin{array}{l}\text { Digoxin, } \\
\text { diuretic }\end{array}$ \\
\hline 26 & 25 & 3 & 3 & 0 & MR 2/4 & $\begin{array}{l}\text { Ant.- } \\
\text { apical }\end{array}$ & 36 & $\begin{array}{l}\text { VG to CFX; } \\
\text { mitral } \\
\text { annuloplasty }\end{array}$ & 7 & $\begin{array}{r}\text { Dyspnoea } \\
\text { grade } 1\end{array}$ & Diuretic \\
\hline 27 & 35 & 4 & 0 & 2 & & Ant. & 80 & & 7 & None & None \\
\hline 28 & 17 & 3 & 2 & 4 & & $\begin{array}{l}\text { Ant.- } \\
\text { apical }\end{array}$ & 50 & $\begin{array}{l}\text { VG and } E \text { to } \\
\text { RCA }\end{array}$ & 6 & None & None \\
\hline 29 & 22 & 4 & 3 & 1 & & Ant. & 24 & VG to CFX & 6 & None & None \\
\hline 30 & 25 & 4 & 2 & 3 & & Ant.-apical & 40 & VG to RCA & 6 & None & None \\
\hline 31 & 35 & 4 & 3 & 4 & & Ant. & 80 & $\begin{array}{l}\text { VG to RCA } \\
\text { and CFX }\end{array}$ & 6 & None & None \\
\hline 32 & 25 & 0 & 4 & 4 & & Post-inf. & 150 & VG to RCA & 6 & None & None \\
\hline
\end{tabular}

$\star$ No coronary arteriogram.

MR, mitral regurgitation (grade); VSD, ventricular septal defect; L, left main coronary artery stenosis; VG, vein graft; E, endarterectomy; LAD, left anterior descending coronary artery; CFX, left circumflex coronary artery; RCA, right coronary artery. 
in cardiogenic shock after a massive recent infarction, the other patient had dyspnoea at rest. There were no deaths in the early postoperative period.

All patients were treated with anticoagulants for three months; digoxin and diuretics were used initially and discontinued when possible (Table 2).

\section{Pathology}

The resected portion of the left ventricle was examined histologically in 30 patients, and was composed of hyalinized fibrous tissue, with a few residual muscle bundles in most cases. The size of the aneurysm ranged from $3 \times 2$ to $15 \times 10 \mathrm{~cm}$ (average $62 \mathrm{~cm}^{2}$ ); one was heavily calcified over $6 \mathrm{~cm}^{2}$.

\section{Follow-up}

This ranged from 6 to 56 months (average 17.8 months). One patient with severe triple vessel disease who did not undergo coronary revascularization had a further myocardial infarction 6 months after operation and died of congestive cardiac failure less than a year later. Cardiovascular symptoms and exercise tolerance improved considerably in all patients. Of the 29 survivors, 18 are now leading a normal active life without drug therapy, 5 are asymptomatic on standard antifailure treatment, requiring less diuretic than in the preoperative period; 2 patients have grade 2 dyspnoea and 1 patient has grade 1 dyspnoea in spite of medical treatment. One patient has recurrent postoperative atrial tachyarrhythmias, partially controlled with beta-adrenergic blocking drugs. Two patients still have grade 2 angina pectoris. One of these did not have vein graft surgery in spite of major lesion in the circumflex artery. The other has been reinvestigated: left ventriculography showed conspicuous improvement in left ventricular function with effective resection of the aneurysmal area; the right coronary artery graft was occluded.

\section{Discussion}

Angiographic criteria for the diagnosis of left ventricular aneurysm are not generally agreed and are unreliable. Since many reported series depend upon the angiogram for diagnosis it is difficult to compare their surgical results. Our patients all had fibrous aneurysms seen at operation and confirmed in the majority by pathological examination of the specimen. The only other series where the same criteria were used was from the Cleveland Clinic
(Loop et al., 1973a). The diagnosis had been made before operation in all except 2 of our patients by the observation of paradoxical movement of a segment of myocardium in systole seen on the left ventriculogram (Gorlin et al., 1967). In our experience, however, the left ventriculogram is not diagnostic in the sense that sometimes we have suspected aneurysm because of paradoxical wall movement, but at subsequent operation a fibromuscular hypokinetic area was found. This difficulty has been noted by others (Yacoub et al., 1973).

All of our patients presented with cardiac symptoms and were investigated for this reason. It is interesting to note, however, that there was no history of systemic emboli despite the fact that 59 per cent of the patients had mural thrombus at the time of operation. A similar incidence of mural thrombus has been previously reported by Dubnow et al. (1965) (65\%) and by Schlichter et al. (1954) (54\%), though these authors also reported a high incidence of arterial emboli (38\% and $64 \%$, respectively); however, both these studies were based on post-mortem material. The Cleveland Clinic group (Loop et al., 1973a) also found that arterial emboli were uncommon; the symptomatology of our patients was in fact similar in most respects to theirs. Other reported series are heavily weighted by patients with one or other dominant symptom, e.g. angina (Rao et al., 1974), congestive cardiac failure (Cooperman et al., 1975), ventricular tachycardia (Hazan et al., 1973). The majority of our patients had persistent dyspnoea after treatment with digitalis and diuretics, and some had frank pulmonary oedema, but more than half also had angina pectoris and this was the dominant symptom in 6 patients. This high incidence of angina was associated with severe coronary disease; only 8 of our patients had an isolated lesion of the left anterior descending coronary artery which was the finding in the majority of patients in the earlier reports (Cooley et al., 1958; Favoloro et al., 1968; Cooley and Hallman, 1968). The differences in patient selection may explain the widely varying operative mortality that has been reported, ranging from nil (Rao et al., 1974) to 32 per cent (Kay et al., 1970). The series reported by Rao et al. (1974) differed from others in that angina was the presenting symptom in 75 per cent of the patients. Our operative mortality figure of 6.2 per cent is very similar to that of Loop et al. (1973a) whose group of patients most closely resembled ours.

Additional aortocoronary bypass grafting was not routine at the beginning of the series but became so later when 15 patients had this done. This has been the common course of events (Merin et al., 1973; 
Loop et al., 1973a; Cooperman et al., 1975). Most of the aneurysms excised were large and only in 3 was the area excised less than $20 \mathrm{~cm}^{2}$. It is not possible to compare this with other surgical series as the area of aneurysm is usually not stated.

The patients who in addition had a ventricular septal defect closed or mitral annuloplasty or valve replacement all survived. A feature of interest in this series is the presence of 2 patients with a large posteroinferior aneurysm in association with a ventricular septal defect. The rarity of posteroinferior aneurysms has been previously observed (Loop et al., 1973b) and in a very large series of 400 patients there were only 11 such cases, in 2 of whom there was an associated ventricular septal defect; both of these patients also survived operation, and showed great symptomatic improvement.

The majority of our patients have improved clinically and 18 are asymptomatic leading a normal life without medical therapy. Only one patient is worse, with increased severity of angina. There has only been 1 late death, 16 months after operation.

Loop et al. (1973a) have attempted to compare surgical with medical treatment and have suggested that the expectation of life is substantially improved by aneurysmectomy. The medical prognosis is, however, judged from post-mortem data which may well be unrepresentative (Schlichter et al., 1954; Dubnow et al., 1965). Data available on the expected mortality of patients with coronary disease and left ventricular dysfunction also suggest a high mortality in patients treated medically; for example, Bruschke, Proudfit, and Sones (1973) report a 46 per cent 5-year cardiac mortality in patients showing dyskinesis (aneurysm) in the left ventricular angiogram.

The low operative mortality, the excellent results in terms of symptomatic relief, and the improved expectation of life after excision of left ventricular aneurysms suggest that operation should be advised in these patients. Aneurysmectomy can be safely combined with aortocoronary bypass grafting, closure of ventricular septal defect, or correction of mitral regurgitation when these additional procedures are indicated.

\section{References}

Austen, W. G., Tsunekawa, T., Bender, H. W., Ebert, P. A., and Morrow, A. G. (1962). The acute hemodynamic effects of left ventricular aneurysm: an experimental study in dogs. Fournal of Surgical Research, 2, 161.

Bruschke, A. V. G., Proudfit, W. L., and Sones, F. M., Jr. (1973). Progress study of 590 consecutive nonsurgical cases of coronary disease followed 5-9 years: II. Ventriculographic and other correlations. Circulation, 47, 1154.

Cooley, D. A., Collins, H. A., Morris, G. C., Jr., and Chap- man, D. W. (1958). Ventricular aneurysm after myocardial infarction. Surgical excision with the use of a temporary cardiopulmonary bypass. Fournal of the American Medical Association, 167, 557.

Cooley, D. A., and Hallman, G. L. (1968). Surgical treatment of left ventricular aneurysm: experience with excision of postinfarction lesion in eighty patients. Progress in Cardiovascular Diseases, 11, 222.

Cooperman, M., Stinson, E. B., Griepp, R. B., and Shumway, N. E. (1975). Survival and function after left ventricular aneurysmectomy. Fournal of Thoracic and Cardiovascular Surgery, 69, 321.

Dubnow, M. H., Burchell, H. B., and Titus, J. L. (1965). Postinfarction ventricular aneurysm: a clinicomorphologic and electrocardiographic study of 80 cases. American Heart fournal, 70, 753.

Favaloro, R. G., Effler, D. B., Groves, L. K., Westcott, R. N., Suarez, E., and Lozada, J. (1968). Ventricular aneurysm: clinical experience. Annals of Thoracic Surgery, 6, 227.

Gorlin, R., Klein, M. D., and Sullivan, J. M. (1967). Prospective correlative study of ventricular aneurysm. Mechanistic concept and clinical recognition. American fournal of Medicine, 42, 512.

Hazan, E., Bloch, G., Rioux, C., Louville, Y., Cirotteau, Y., and Mathey, J. (1973). Surgical treatment of aneurysm and segmental dyskinesia of the left ventricular wall after myocardial infarction. American fournal of Cardiology, 31, 708.

Kay, J. H., Dunne, E., Krohn, B. G., Tsuji, H. K., Redington, J. V., Mendez, A., Dykstra, P., and Magidson, O. (1970). Left ventricular excision, exclusion, or plication for akinetic areas of the heart. Fournal of Thoracic and Cardiovascular Surgery, 59, 139.

Loop, F. D., Effler, D. B., Navia, J. A., Sheldon, W. C., and Groves, L. K. (1973a). Aneurysms of the left ventricle: survival and results of a ten-year surgical experience. Annals of Surgery, 178, 399.

Loop, F. D., Effler, D. B., Webster, J. S., and Groves, L. K. (1973b). Posterior ventricular aneurysms: etiologic factors and results of surgical treatment. New England Fournal of Medicine, 288, 237.

McConahay, D. R., McCallister, B. D., Hallermann, F. J., and Smith, R. E. (1970). Comparative quantitative analysis of the electrocardiogram and the vectorcardiogram. Circulation, 42, 245.

Merin, G., Schattenberg, T. T., Pluth, J. R., Wallace, R. B., and Danielson, G. K. (1973). Surgery for postinfarction ventricular aneurysm. Annals of Thoracic Surgery, 15, 588.

Mourdjinis, A., Olsen, E., Raphael, M. J., and Mounsey, J. P. D. (1968). Clinical diagnosis and prognosis of ventricular aneurysm. British Heart fournal, 30, 497.

Rao, G., Zikria, E. A., Miller, W. H., Samadani, S. R., and Ford, W. B. (1974). Experience with sixty consecutive ventricular aneurysm resections. Circulation, 49-50, Suppl. II, 149.

Rosenbaum, M. B., Elizari, M. V., and Lazzari, J. O. (1970). The Hemiblocks: New Concepts of Intraventricular Conduction Based on Human Anatomical, Physiological and Clinical Studies. Tampa Tracings, Oldsmar, Florida.

Schlichter, J., Hellerstein, H. K., and Katz, L. N. (1954). Aneurysm of the heart: a correlative study of 102 proved cases. Medicine, $\mathbf{3 3}, \mathbf{4 3}$.

Yacoub, M., Knight, E., Towers, M., and Somerville, W. (1973). Left ventricular aneurysm: current appraisal (abstract). British Heart fournal, 35, 866.

Requests for reprints to Dr. R. M. Donaldson, The London Chest Hospital, Bonner Road, London E2 9JX. 